of a sentence from our preface. What we wrote was as follows

The representative conference held in Edinbargh in connexion with the annual meeting of the National Association for the Prevention of Consumption in July, 1910, although divided as to the form which State intervention should take, was practically unanimous in the opinion that some form of such intervention was necessary, and the proposition was supported by leading administrative officers in some of the largest cities in the kingdom.

Is this comment either ambiguous or misleading? If so, then the special Sanitary Commissioner of the Lancet was also in error in his account (July 9th, 1910, p. 120) of the debate on this question at the conference. $\mathrm{He}$ wrote :

The Conference was unanimous as to the issue, the only difference being whether the desired legislation should be part of a general scheme or a law dealing only with tuberculosis.

-We are, etc.

Isondon, W., Jan. 24th.

Arthor Latham,

Charles H. Gartand.

\section{HYPERCHLORHYDRIA AND ITS} COMPLICATIONS.

SiR,-It would not have occurred to me that the readers of the British Medical Journas were so deficient in literary intelligence as not to perceive that my lecture on the above subject was a condensed representation of my own views and experience, and that the reason for the selection of the subject of lecture was that other views, within recent months, had been expressed in the pages of the medical journals. Dr. George Herschell appears to heve some anxiety on this point, but I should hope that on this, as on other pointe, Dr. Herschell's judgement is in error.

I am quite aware that several morbid conditions may simulate, and are not infrequently mistaken for, hyperchlorhydria; also that other morbid conditions may be associated with hyperchlorhydria. The business of the physician is to differentiate these. To state, as Dr. Herschell states, that the symptoms of hyperchlorhydria may be present without over-secretion, or even without the presence of free acid, means, of course, that the symptoms have been misinterpreted.

I believe that hyperchlorhydria is a clinical entity, and that some stomachs are more sensitive than others to the acid. Dr. Herschell apparently does not recognize these cases, and I do not venture to think that anything I could say would lead him to my view.

I shall only refer to one other point, as it seems to me to reveal the character of his criticism. He quotes from my lecture where I refer to chronic ulceration as follows: "Were it established that a serum treatment had been found which ensured the healing of chronic ulcerations" and he goes on to say in the last paragraph of his letter, "He (Dr. Russell) evidently is unscquainted with the treatment by antilytic horse serum." May I suggest that here again Dr. Herschell shows a defect in literary perception? I used the word "established" deliberately. I am acquainted with the contentions regarding the serum mentioned, but I hold that these claims have not yet been established.-I am, etc.,

Edinburgh, Jan. 23rd.

William Rosseli.

THE CAUSE OF APPENDICITIS.

SIR,-I was for three years working in mission hospitals in the North-West Provinces of India-1905 to 1908 During this time we dealt with approximately 20,000 patients, and among these I saw 5 cases of appendicitis, 2 of which were taberculous.-I am, etc.

Elstree, Jan. 17th.

H. B. HaNson.

SHIP SURGEONS

Sir,-Some time ago, in the British Medical Journat, I stated that the White Star, Cunard, American, Dominion, and Leyland Companies had printed a notice to the effect that their surgeons are permitted to charge reasonable fees for the treatment of saloon passengers when the illnesses of passengers are due to causes originating before coming on board. I am glad to say that the Allan, Canadian Pacific and Booth Steamship Companies have lately adopted a similar notice. I wish to suggest that if the medicals practising in each seaport town would bring the action of these companies to the notice of their local steamship companies, and in a quiet way, they might be induced to follow the Liverpool system.-I am, etc.,

Liverpool, Jan. 23rd.

R. R. Rentodi.

RESEARCH DEFENCE SOCIETY.

Sir,-As it is just three years since the Research Defence Society was formed (January 27th, 1908), we hope that you will kindly find room for a short account of its work during the past year. The number of membere, which was about 2,800 a year ago, is now 3,770 , and the number of associates, which was 130 , is now 230. Six new branch societies have been formed, making nineteen in all. Since January last the following have consented to be Vice-Presidents of the Society: The Bishop of St. Asaph, Miss Balfour, Sir George Beatson, Dr. M. G. Biggs, Sir John Carrington, Lord Hugh Cecil, the Bishop of Chichester, the Earl of Durham, the Bishop of Ely, Sir David Gill, Sir Archibald Hepburn, Lord Kenyon, Professor Leitb, the Dake of Norfolk, the Bishop of Nyasaland, Mrs. Henry Sidgwick, the Bishop of Stepney, and Archdeacon Watking.

Since January last the following pamphlets and leaflets have been published by the Society: (1) Pasteur, Science, and Medicine, (2) The Nation and the Tropics, (3) Plague in India, past and present, (4) The Helpfulness of Physiological Experiments to the General Practitioner, (5) Report of Annual General Meeting, (6) Diphtheria and Antitoxin (7) Inoculations, (8) Experiments during 1909, (9) Charges of Cruelty against the Rockefeller Institute, (10) Fighting the Invisible, (11) What the Doctor sa,ys, (12) The National Welfare, (13) The Brown Dog, (14) A Question of Religion; (15) The Research Defence Society, (16) Sleoping Sickness, (17) Malta Fever, (18) Experiments on Dogs, (19) In Memoriam, Louis Pasteur, (20) Humanity and Science, (21) Friends of Animals.

There has been a very great increase during the past year in the quantity of pamphlets and leaflets distributed, and in the number of addresses and popular lectures and lantern lectures given by members of the society in all parts of the country. Many debates also have been attended in London or elsewhere by the society's repre. sentatives, with excellent results. We are constantly finding that the great majority of the audience on these occasions, after hearing both sides, is strongly in favour of the views of our society.

A large quantity of our publications has been distributed among Pablic Libraries and similar institutes; a large quantity, also, is sold in the ordinary way of publication.

During the past few months the society has been represented by stalls held at the following exhibitions: the Church Congress, the Annual Meeting of the British Medical Association, the Kennel Club Show, and the Birmingham Dog Show.

The Research Defence Society has nothing to do with the actual making of experiments on animale, nor with the administration of the Act: nor does it desire to see the abolition of restrictions on experiments on animals in this country. It keeps itself to the work for which it was formed three years ago: that is, to make generally known the facts as to experiments on animals in this country and the regulations under which they are conducted, the im mense importance of such experiments to the welfare of mankind, and the great saving of human and animal life and health which is already due to them.

We hope that many of your readers will become mem. bers or associates of the society, and will help to extend its educational work.-We are, etc.

$$
\text { Cromer, }
$$
President.

Sydney Holland, Chairman of Committee. F. M. Sandwith, Honorary Treasurer.

Stephen Paget, Honorary Becretary:

21, Ladbroke Square, London, W., Jan. 25th 